\title{
Use of sweet yellow clover (Melilotus officinalis) extract in sheep feeding
}

\author{
Elena Ulrikh, ${ }^{1, *}$, Olga Babich $^{2,3}$, and Stanislav Sukhikh ${ }^{2,3}$ \\ ${ }^{1}$ Kuzbass State Agricultural Academy, 5 Markovtsev St., 650056 Kemerovo, Russia \\ ${ }^{2}$ Immanuel Kant Baltic Federal University, 14 A. Nevsky St., 236016 Kaliningrad, Russia \\ ${ }^{3}$ Kemerovo State University, 6 Krasnaya St., 650000 Kemerovo, Russia
}

\begin{abstract}
During the study, it was found that an increase in the dose of sweet yellow clover extract from 0.5 to $2.5 \mathrm{mg} / \mathrm{kg}$ of live weight per day contributed to an increase in the number of: hemoglobin by $1.83 \mathrm{~g} / 1(1.79 \%)$, leukocytes by 0.14 thousand $109 / 1(2.34 \%)$, total protein in blood serum of sheep by $0.43 \mathrm{~g} / 1(0.7 \%)$, glucose in blood of sheep by $0.18 \mathrm{mmol} / 1(4.19 \%)$, calcium in blood of sheep by $0.14 \mathrm{mmol} / 1(5.32 \%)$, phosphorus in blood of sheep by only $0.08 \mathrm{mg} / 100 \mathrm{ml}(1.6 \%)$, contributed to an increase in the live weight of sheep by $220 \mathrm{~g}(2.18 \%)$. In the control group, two sheep out of six got bronchitis. The percentage of sheep with bronchitis was $33.33 \%$. After feed to the sheep different doses of sweet yellow clover extract, the sheep in groups I and II of the experimental groups had one sheep each (16.67\%), while in groups III, IV and V there were no sheep with bronchitis. Thus, increasing the sweet yellow clover dosage in sheep' diet reinforced their immunity. In the control group and in the first experimental group, one sheep out of six came down with dyspepsia. The percentage of sheep with dyspepsia was $16.67 \%$. After feed to the sheep doses of sweet yellow clover extract, there were no dyspeptic diseases in sheep.
\end{abstract}

\section{Introduction}

In recent decades, global meat production has been steadily increasing [1]. Given the steady growth of the population, this trend is projected to continue in the near future. Thus, modern livestock farming is supported by efficient production methods to supply high quality and safe livestock products to food chains while maintaining profitability for producers [2]. Increased demand for animal protein, on the one hand, and stricter rules for livestock intake on the other hand, animal welfare and environmental protection, further improvements in modern production technologies are now necessary [3, 4]. In particular, feed conversion rate is calculated as the amount of feed consumed per unit of gain of body weight, egg or milk, and it is a key parameter that should be improved in the coming decades [5]. The contribution of feed costs to the total production cost is $60-70 \%$. Thus, optimizing the use of feed is the key to sustainable and profitable livestock production. An animal requires a certain level of nutrients to meet its metabolic process needs, such as basic body functions and building

${ }^{*}$ Corresponding author: elen.ulrich@mail.ru 
muscle tissue, or egg or milk production. In most of the world, protein and phosphorus are the most expensive feed ingredients [6]. Consequently, it is imperative to use them in the most efficient way to optimize feed efficiency [7, 8].

Growth stimulants and antibiotics were, and in many countries remain, constant inclusions in animal diet in therapeutic concentrations to achieve better feed conversion and higher growth rates by reducing the activity of the digestive tract microbiota [9]. Nevertheless, the constant use of growth stimulants and antibiotics in animal diets has been connected with bacterial resistance development to several antibiotic agents [10]. While scientists continue to investigate the actual impact of widespread use of growth promoters and antibiotics in animal feed on human microbial resistance, consumers are becoming increasingly aware of negative effects of so-called superbacteria (bacteria that are highly resistant to antibiotics). A total ban on antibiotics and growth promoters was introduced in Europe in 2006 as a result of growing public concern [11]. Meanwhile, the ban on antibiotics and growth promoters has become a worldwide trend, and many countries outside the European Union are on their way to restricting or banning the use of antibiotics and growth promoters in animal feed [12]. For example, Korea banned the use of antibiotics and growth promoters in animal feed in 2011. However, solutions are being sought not only to replace antibiotics and growth stimulants in animal feed, but also to reduce the overall use of veterinary antibiotics in farm animal production [13-15].

The paper's goal - to study the effect of sweet yellow clover on physiological status of Edilbay sheep.

\section{Materials and Methods}

The study's objects in the work were:

- Edilbay sheep;

- Edilbay sheep blood;

- $\quad$ sweet yellow clover (Melilotus officinalis).

To assess the impact on the complex of economically useful qualities of sheep, a scientific and economic experiment on Edilbay sheep was carried out.

To conduct experimental study on Edilbay sheep formed a control and 5 experimental groups, 6 heads in each group. Animals were matched by age and body weight. The sheep of the control group received the basic diet, lambs of the experimental groups received in addition the medicinal plant extract, sweet yellow clover, according to the experimental scheme. Six sheep were selected in each of the six groups.

Control - basic diet (BD)

Experimental I - BD $+0.5 \mathrm{mg} / \mathrm{kg}$ live weight per day of sweet yellow clover

Experimental II - BD $+1.0 \mathrm{mg} / \mathrm{kg}$ live weight per day of sweet yellow clover

Experimental III - BD $+1.5 \mathrm{mg} / \mathrm{kg}$ live weight per day of sweet yellow clover

Experimental IV - BD $+2.0 \mathrm{mg} / \mathrm{kg}$ live weight per day of sweet yellow clover

Experimental V - BD $+2.5 \mathrm{mg} / \mathrm{kg}$ live weight per day of sweet yellow clover

The sweet yellow clover extract was administered individually. The contents (with a certain dose for each animal) were diluted in $5 \mathrm{ml}$ of boiled and cooled water and after dissolution were given to calves. The solutions were prepared before use. We started to give it from the 15 th day after birth, 1 hour before or during the next feeding, 1 dose per day for 15 days.

Biochemical blood test

Biochemical blood tests of calves are carried out as follows:

1. Blood sampling and preparation of blood samples from calves for the study is carried out at the age of 15, 30 days. Blood is taken from the tail or jugular vein in two tubes. 
Blood sampling for biochemical studies is performed using vacuum systems with clotting activator (silicon sputtering) serum.

2. Determination of biochemical indicators is carried out by methods, according to the instructions for the use of reagents for biochemical studies conducted on an automated biochemical analyzer AU 480:

a. total protein - by photometry in the visible range,

b. glucose - by enzymatic method in the UV range,

c. total calcium - by photometry in the visible range,

d. inorganic phosphorus - by photometry in the visible range,

3. According to the results of biochemical studies form a test report, which makes a conclusion on the biochemical processes occurring in calf body;

Hematological blood tests

Hematological blood tests of young animals are carried out as follows:

1. Blood sampling and preparation of blood samples from calves for the study is carried out at the age of 15, 30 days. Blood is drawn from jugular vein in the morning hours before feeding. Blood is taken in $4 \mathrm{ml}$ vacuum tubes with $\mathrm{K} 3$ EDTA to determine the studied parameters. The blood in the tubes after collection is well mixed with the stabilizer by tilting it from side to side by $180^{\circ}$ up to $8-10$ times. The sample should not be shaken - it can cause hemolysis. The tubes with material are then placed vertically in a holder, and the sample number, animal number, and sex are recorded in a blood sampling protocol. Within 4 hours, the samples are taken to the research laboratory for analysis.

2. To determine hematological parameters, the following 4 parameters are used: RBC erythrocytes, WBC leukocytes, HGB hemoglobin. The tests are performed on a veterinary hematology analyzer VetScan HM5 Abaxis. The physiological values are based on the reference values of the analyzer VetScan HM5 Abaxis Veterinary Hematology.

\section{Results and Discussion}

Blood is the most important indicator characterizing the intensity of oxidative processes in the body [13]. Blood, as the internal environment of the body, has a relative constancy in its composition. However, this system reflects, to a greater or lesser degree, all the changes that occur in the body [10]. Hematological blood parameters are interrelated with animal productivity. In this regard, we used biochemical blood indicators to evaluate the economically useful features of animals. Blood was taken from the animals in the morning, at the same time, before feeding and watering.

The amount of hemoglobin in sheep blood after feeding the sweet yellow clover extract is presented in Table 1.

Table 1. Amount of hemoglobin in sheep blood after feeding the sweet yellow clover extract, $\mathrm{g} / 1$

\begin{tabular}{|c|c|c|c|c|c|c|}
\hline \multirow{2}{*}{ Animal's No. } & \multirow{2}{*}{$\begin{array}{c}\text { Control } \\
\text { group }\end{array}$} & \multicolumn{5}{|c|}{ Experimental groups } \\
\cline { 3 - 7 } & & I & II & III & IV & V \\
\hline 1 & 98 & 104 & 101 & 106 & 105 & 107 \\
\hline 2 & 102 & 97 & 106 & 105 & 99 & 104 \\
\hline 3 & 105 & 98 & 104 & 99 & 108 & 102 \\
\hline 4 & 96 & 107 & 100 & 104 & 105 & 98 \\
\hline 5 & 99 & 108 & 98 & 106 & 104 & 105 \\
\hline 6 & 104 & 99 & 105 & 103 & 106 & 108 \\
\hline \multirow{2}{*}{ average value } & $100.67 \pm$ & $102.17 \pm$ & $102.33 \pm$ & $103.83 \pm$ & $104.5 \pm$ & $104.0 \pm$ \\
& 1.59 & 2.14 & 1.4 & 1.18 & 1.35 & 1.62 \\
\hline Norma & \multicolumn{7}{|c|}{$94-113$} \\
\hline
\end{tabular}


In our studies, the amount of hemoglobin in all groups corresponded to normal values. Fluctuations ranged from 96.0 to $108.0 \mathrm{~g} / \mathrm{l}$. The average index in the $\mathrm{V}$ experimental group exceeded the control by $3.33 \mathrm{~g} / \mathrm{l}(3.31 \%)$, which allows to increase the transport of oxygen and carbon dioxide and increase the metabolism. Increasing the sweet yellow clover extract from 0.5 to $2.5 \mathrm{mg} / \mathrm{kg}$ of live weight per day increased the amount of hemoglobin by $1.83 \mathrm{~g} / \mathrm{l}$ $(1.79 \%)$.

The amount of leukocytes in sheep blood after feeding the sweet yellow clover extract is presented in Table 2.

Table 2. Amount of leukocytes in sheep blood after feeding the sweet yellow clover extract, thousand $10^{9} / 1$

\begin{tabular}{|c|c|c|c|c|c|c|}
\hline \multirow{2}{*}{ Animal's No. } & Control group & \multicolumn{7}{|c|}{ Experimental groups } \\
\cline { 3 - 7 } & & I & II & III & IV & V \\
\cline { 2 - 7 } & 5.5 & 6.6 & 5.9 & 6.0 & 6.3 & 6.1 \\
\hline 1 & 5.8 & 6.3 & 6.6 & 6.2 & 5.9 & 6.3 \\
\hline 2 & 6.7 & 5.4 & 6.3 & 5.9 & 6.5 & 5.8 \\
\hline 3 & 6.1 & 6.2 & 5.7 & 5.8 & 6.2 & 6.3 \\
\hline 4 & 5.4 & 5.8 & 6.2 & 6.6 & 5.9 & 6.0 \\
\hline 5 & 6.2 & 5.6 & 5.8 & 6.3 & 6.1 & 6.2 \\
\hline 6 & $5.95 \pm 0.22$ & $5.98 \pm 0.20$ & $6.08 \pm 0.22$ & $6.13 \pm 0.13$ & $6.15 \pm 0.1$ & $6.12 \pm 0.09$ \\
\hline \multirow{2}{*}{ average value } & & & & & \\
\hline Norma & & \multicolumn{7}{|c|}{$5.1-8.0$} & & \\
\hline
\end{tabular}

In our studies, this indicator was normal, that can say about the good state of sheep. The difference between the control and $\mathrm{V}$ experimental groups in leukocytes was 0.17 thousand per $10^{9} / 1(2.85 \%)$.

Increasing the sweet yellow clover extract from 0.5 to $2.5 \mathrm{mg} / \mathrm{kg}$ of live weight per day reduced the amount of leukocytes by 0.14 thousand $10^{9} / 1(2.34 \%)$.

The content of total protein in blood serum of sheep after feeding the sweet yellow clover extract is presented in Table 3 .

Table 3. Total protein content in blood serum of sheep after feeding the sweet yellow clover, $g / 1$

\begin{tabular}{|c|c|c|c|c|c|c|}
\hline \multirow{2}{*}{$\begin{array}{l}\text { Animal's } \\
\text { No. }\end{array}$} & \multirow{2}{*}{ Control group } & \multicolumn{5}{|c|}{ Experimental groups } \\
\cline { 3 - 7 } & & I & II & III & IV & V \\
\hline 1 & 60.3 & 61.4 & 60.9 & 61.7 & 62.0 & 61.3 \\
\hline 2 & 59.8 & 60.8 & 61.5 & 62.1 & 61.7 & 62.1 \\
\hline 3 & 61.2 & 60.9 & 61.4 & 61.5 & 62.1 & 61.7 \\
\hline 4 & 62.0 & 59.2 & 61.8 & 60.9 & 61.6 & 60.4 \\
\hline 5 & 60.3 & 62.1 & 59.9 & 61.6 & 60.3 & 61.5 \\
\hline 6 & 61.1 & 61.6 & 62.1 & 60.0 & 61.2 & 61.6 \\
\hline $\begin{array}{c}\text { average } \\
\text { value }\end{array}$ & $60.78 \pm 0.36$ & $61.0 \pm 0.45$ & $61.27 \pm 0.35$ & $61.3 \pm 0.33$ & $61.48 \pm 0.3$ & $61.43 \pm 0.26$ \\
\hline Norma & & \multicolumn{7}{|c|}{$60.0-62.0$} & & \\
\hline
\end{tabular}

The content of total protein in blood serum of sheep after feeding the sweet yellow clover extract both in the control and experimental groups was within the physiological norm. In the $\mathrm{V}$ experimental group, the content of total protein was higher than in the control by $0.65 \mathrm{~g} / \mathrm{l}$ $(1.07 \%)$.

Increasing the sweet yellow clover extract from 0.5 to $2.5 \mathrm{mg} / \mathrm{kg}$ of body weight per day led to a slight increase in the amount of total protein in blood serum of sheep by $0.43 \mathrm{~g} / \mathrm{l}$ $(0.7 \%)$.

The blood serum glucose content of sheep after feeding the sweet yellow clover extract is presented in Table 4. 
Table 4. Glucose content in blood serum of sheep after feeding the sweet yellow clover, $\mathrm{mmol} / \mathrm{l}$

\begin{tabular}{|c|c|c|c|c|c|c|}
\hline \multirow{2}{*}{ Animal's No. } & \multirow{2}{*}{ Control group } & \multicolumn{5}{|c|}{ Experimental groups } \\
\cline { 3 - 7 } & & I & II & III & IV & V \\
\hline 1 & 4.2 & 4.5 & 4.2 & 4.3 & 4.7 & 4.6 \\
\hline 2 & 4.5 & 4.1 & 4.4 & 4.5 & 4.3 & 4.4 \\
\hline 3 & 4.4 & 4.3 & 4.6 & 4.4 & 4.5 & 4.3 \\
\hline 4 & 4.2 & 4.4 & 4.5 & 4.6 & 4.5 & 4.4 \\
\hline 5 & 4.0 & 4.2 & 4.3 & 4.4 & 4.6 & 4.5 \\
\hline 6 & 4.1 & 4.3 & 4.5 & 4.5 & 4.4 & 4.7 \\
\hline average value & $4.23 \pm 0.08$ & $4.3 \pm 0.06$ & $4.42 \pm 0.07$ & $4.45 \pm 0.05$ & $4.5 \pm 0.06$ & $4.48 \pm 0.07$ \\
\hline Norma & \multicolumn{7}{|c|}{$4.1-4.7$} \\
\hline
\end{tabular}

In our studies, this index ranged from 4.0 to $4.7 \mathrm{mmol} / \mathrm{l}$ and was within the physiological norm. In the $\mathrm{V}$ experimental group, the average glucose content was $0.25 \mathrm{mmol} / 1(5.9 \%)$ higher than in the control group.

Increasing the sweet yellow clover extract from 0.5 to $2.5 \mathrm{mg} / \mathrm{kg}$ of live weight per day increased the amount of glucose in blood in sheep by $0.18 \mathrm{mmol} / \mathrm{l}(4.19 \%)$.

The calcium content in blood serum of sheep after feeding the sweet yellow clover extract is presented in Table 5 .

Table 5. Calcium content in blood serum of sheep after feeding the sweet yellow clover, $\mathrm{mmol} / \mathrm{l}$

\begin{tabular}{|c|c|c|c|c|c|c|}
\hline \multirow{2}{*}{$\begin{array}{c}\text { Animal's } \\
\text { No. }\end{array}$} & \multirow{2}{*}{ Control group } & \multicolumn{5}{|c|}{ Experimental groups } \\
\cline { 3 - 7 } & & I & II & III & IV & V \\
\hline 1 & 5.0 & 4.9 & 5.4 & 5.1 & 5.3 & 4.8 \\
\hline 2 & 4.7 & 4.8 & 5.2 & 4.8 & 5.2 & 5.3 \\
\hline 3 & 4.6 & 5.2 & 4.8 & 5.0 & 4.9 & 5.1 \\
\hline 4 & 5.9 & 4.6 & 4.9 & 4.9 & 5.1 & 5.2 \\
\hline 5 & 4.8 & 5.6 & 4.8 & 5.2 & 4.7 & 4.8 \\
\hline 6 & 4.6 & 4.7 & 4.6 & 5.4 & 5.0 & 5.1 \\
\hline $\begin{array}{c}\text { average } \\
\text { value }\end{array}$ & $4.93 \pm 0.22$ & $4.97 \pm 0.17$ & $4.95 \pm 0.13$ & $5.07 \pm 0.10$ & $5.03 \pm 0.10$ & $5.05 \pm 0.09$ \\
\hline Norma & \multicolumn{7}{|c|}{$4.5-6.0$} \\
\hline
\end{tabular}

In our studies, the calcium content in blood serum of sheep after feeding the sweet yellow clover extract was mainly within the physiological norm. Values ranged from 2.4 to 3.1 $\mathrm{mmol} / \mathrm{l}$. The average value in the $\mathrm{V}$ experimental group was higher by $0.12 \mathrm{mmol} / 1(4.53 \%)$ than in the control group. This helps to better protect the body from dyspepsia and bronchitis.

Increasing the sweet yellow clover extract from 0.5 to $2.5 \mathrm{mg} / \mathrm{kg}$ of live weight per day increased the amount of calcium in blood in sheep by $0.14 \mathrm{mmol} / \mathrm{l}(5.32 \%)$

The phosphorus content in blood serum of sheep after feeding the sweet yellow clover extract is presented in Table 6 .

Table 6. Phosphorus content in blood serum of sheep after feeding the sweet yellow clover, $\mathrm{mg} / 100 \mathrm{ml}$

\begin{tabular}{|c|c|c|c|c|c|c|}
\hline \multirow{2}{*}{$\begin{array}{c}\text { Animal's } \\
\text { No. }\end{array}$} & \multirow{2}{*}{$\begin{array}{c}\text { Control } \\
\text { group }\end{array}$} & \multicolumn{5}{|c|}{ Experimental groups } \\
\cline { 3 - 7 } & I & II & III & IV & V \\
\hline 1 & 5.0 & 4.9 & 5.4 & 5.1 & 5.3 & 4.8 \\
\hline 2 & 4.7 & 4.8 & 5.2 & 4.8 & 5.2 & 5.3 \\
\hline 3 & 4.6 & 5.2 & 4.8 & 5.0 & 4.9 & 5.1 \\
\hline 4 & 5.9 & 4.6 & 4.9 & 4.9 & 5.1 & 5.2 \\
\hline 5 & 4.8 & 5.6 & 4.8 & 5.2 & 4.7 & 4.8 \\
\hline 6 & 4.6 & 4.7 & 4.6 & 5.4 & 5.0 & 5.1 \\
\hline $\begin{array}{c}\text { average } \\
\text { value }\end{array}$ & $4.93 \pm 0.22$ & $4.97 \pm 0.17$ & $4.95 \pm 0.13$ & $5.07 \pm 0.10$ & $5.03 \pm 0.10$ & $5.05 \pm 0.09$ \\
\hline Norma & \multicolumn{7}{|c|}{$4.5-6.0$} \\
\hline
\end{tabular}


In our studies, the phosphorus content in blood serum of sheep after feeding the sweet yellow clover extract was within the physiological norm. The values in the groups ranged from 4.6 to $5.9 \mathrm{mg} / 100 \mathrm{ml}$. The average value in the $\mathrm{V}$ experimental group was slightly higher by $0.12 \mathrm{mg} / 100 \mathrm{ml}(2.43 \%)$ than in the control group.

Increasing the sweet yellow clover extract from 0.5 to $2.5 \mathrm{mg} / \mathrm{kg}$ of live weight per day increased the amount of phosphorus in blood in sheep by only $0.08 \mathrm{mg} / 100 \mathrm{ml}(1.6 \%)$

The live weight of Edilbay sheep throughout the experiment was within the norm for this breed and age.

The live weight of sheep after feeding the sweet yellow clover extract is presented in Table 7.

Table 7. Live weight of sheep after feeding the sweet yellow clover extract, $\mathrm{kg}$

\begin{tabular}{|c|c|c|c|c|c|c|}
\hline \multirow{2}{*}{$\begin{array}{l}\text { Animal's } \\
\text { No. }\end{array}$} & Control group & \multicolumn{5}{|c|}{ Experimental groups } \\
\cline { 3 - 7 } & & I & II & III & IV & V \\
\hline 1 & 10.1 & 10.4 & 9.8 & 10.0 & 9.9 & 10.3 \\
\hline 2 & 9.8 & 10.0 & 9.9 & 10.2 & 10.0 & 10.5 \\
\hline 3 & 10.0 & 9.9 & 10.5 & 9.9 & 10.3 & 10.2 \\
\hline 4 & 9.6 & 10.7 & 9.9 & 10.3 & 10.2 & 10.4 \\
\hline 5 & 10.0 & 9.8 & 10.2 & 10.5 & 10.3 & 10.1 \\
\hline 6 & 9.8 & 9.7 & 10.1 & 9.9 & 10.5 & 10.3 \\
\hline $\begin{array}{c}\text { average } \\
\text { value }\end{array}$ & $9.88 \pm 0.08$ & $10.08 \pm 0.17$ & $10.07 \pm 0.12$ & $10.13 \pm 0.11$ & $10.2 \pm 0.1$ & $10.3 \pm 0.06$ \\
\hline
\end{tabular}

The live weight of sheep in the experimental groups, after feeding the sweet yellow clover extract, ranged from $9.7 \mathrm{~kg}$ to $10.7 \mathrm{~kg}$. In the control group, this indicator was lower and ranged from $9.6 \mathrm{~kg}$ to $10.1 \mathrm{~kg}$. The difference between the average values in the control and $\mathrm{V}$ experimental groups was $420 \mathrm{~g}$ or $4.25 \%$. We explain it by the increase of metabolism, normalization of acetic-alkali equilibrium.

Increasing the sweet yellow clover extract from 0.5 to $2.5 \mathrm{mg} / \mathrm{kg}$ live weight per day increased the live weight of sheep by $220 \mathrm{~g}(2.18 \%)$.

In the control group, two sheep out of six got bronchitis. The percentage of sheep with bronchitis was $33.33 \%$. After feed to the sheep different doses of sweet yellow clover extract, the sheep in groups I and II of the experimental groups had one sheep each (16.67\%), while in groups III, IV and V there were no sheep with bronchitis. Thus, increasing the sweet yellow clover dosage in sheep' diet reinforced their immunity.

In the control group and in the first experimental group, one sheep out of six came down with dyspepsia. The percentage of sheep with dyspepsia was $16.67 \%$. After feed to the sheep doses of sweet yellow clover extract, there were no dyspeptic diseases in sheep. In the control group, one sheep out of 6 died. The percentage of died sheep in the group was $16.67 \%$. There were no died sheep after feeding the sheep with sweet yellow clover extract.

\section{Conclusions}

Thus, the tests conducted on the use of different dosages of the sweet yellow clover extract in diets of sheep showed that the biochemical blood composition improves and the protective body functions increase. The best performance among experimental groups were in sheep of the experimental group $\mathrm{V}$, which received $2.5 \mathrm{mg} / \mathrm{kg}$ of live weight of the sweet yellow clover extract.

\section{References}

1. D. E. Cross, K. Svoboda, R. M. McDevitt, T. Acamovic, Brit Poult Sci., 44 (2021) 
2. P. Dansou, M. Moudachirou, S. O. Kotchoni, Mol Biol Rep., 40 (2013)

3. O. R. Davies, M. R. Kare, R. A. Cagan, Anat Rec., 195 (2019)

4. J. J. Dibner, J.D. Richards, Poult Sci., 84 (2017)

5. H. J. D. Dorman, S. G. Deans, J Appl Microbiol., 88 (2020)

6. A. A. El-Deek, M. A. Al-Harthi, M. Osman, F. Al-Jassas, R. Nassar, Arch Geflügelkd., 76 (2018)

7. R. M. Engberg, K. Grevsen, E. Ivarsen, X. Frette, L.P. Christensen, O. Hojberg, B. B. Jensen, N. Canibe, Avian Pathol., 41 (2016)

8. O. N. Ertas, T. Gu“ler, M. C, iftc, ,i, B. Dalkilic, U.G. Simsek, Int Poult Sci., 4 (2015)

9. V. I. Fisinin, G.Yu. Laptev, I.A. Egorov, A. A. Grozina, Sergiev Posad., 6 (2017)

10. J. R. Ganchrow, D. Ganchrow, Anat Rec., 218 (2017)

11. S. Jayakumar, N. Baskaran, R. Arumugam, S. Sathiskumar, M. Pugazhenthi, South African Journal of Botany, 118 (2018)

12. K. Ognik, E. Cholewinska, I. Sembratowicz, E.R. Grela, A. Czech, World's Poultry Sci. J., 72, 291 (2016)

13. A. Paskudska, D. Kołodziejczyk, S. Socha, Acta Sci. Pol. Zootechnica., 17 (2018)

14. R. Singh, K. K. Chahal, Int. J. Chem. Studies., 16 (2018)

15. Sh. Vaswani, V. K. Sidhu, D. Roy, M. Kumar, R. Kushwaha, International Journal of Livestock Research., 13 (2017) 